\title{
The vowesses, the anchoresses and the aldermen's wives: Lady Margaret Beaufort and the devout society of late medieval Stamford
}

\author{
Rachel M. Delman ${ }^{* \dagger}$ (D) \\ King's Manor K/G86, Department of History, University of York, King's Manor, York, YO1 7EP, UK \\ ${ }^{*}$ Corresponding author. Email: rachel.delman@york.ac.uk
}

\begin{abstract}
This article investigates a devout society centring on the household of Margaret Beaufort (d. 1509) at Collyweston in Northamptonshire and St Katherine's guild in the neighbouring market town of Stamford in Lincolnshire. The discussion unveils Margaret Beaufort's place at the heart of a vibrant devotional community, whose members, among them a core group of lay and religious townswomen, were united by their geography and shared devotional interests. Ultimately, this article sheds new light on the overlapping spiritual networks of an important market town and the household of a highly influential noblewoman, whilst also demonstrating how Margaret's sponsorship of the society informed her self-fashioning as a pious matriarch of the house of Tudor.
\end{abstract}

In her last will and testament of 1508, Margaret Beaufort, mother of King Henry VII and countess of Richmond and Derby, made provisions for the support and maintenance of two anchoresses named Margaret White and Agnes Leche, both of whom were resident in the market town of Stamford. ${ }^{1}$ White's cell was attached to the Priory of St Michael, a Benedictine nunnery which stood on the southwestern side of the town, in an area then known as Stamford Baron or Stamford St Martin's. ${ }^{2}$ Leche, meanwhile, was immured on the north side of the parish

\footnotetext{
'An early version of this article was presented at the 'Lincolnshire in the Wars of the Roses' conference, which was organized by the Lincoln Record Society and held in September 2019. I am grateful to Paul Dryburgh and Marianne Wilson for the invitation to participate, and to the attendees for their questions and comments. I would like to thank Alan Rogers for generously sharing his extensive knowledge of late medieval Stamford with me, and for commenting on earlier drafts of this article. My thanks also go to Sarah Rees Jones, Jeremy Goldberg, Pat Cullum, Nicola McDonald, Laura Varnam and two anonymous peer reviewers for their constructive comments on earlier versions of this article, and to Laura Wood for our ongoing conversations about vowesses. Any mistakes that remain in the text are my own. The funding of the Arts and Humanities Research Council and the Leverhulme Trust is gratefully acknowledged.

'‘Will of Margaret Beaufort', in The St John's College Quatercentenary Volume: Collegium Divi Johannis Evangelistae, 1511-1911 (Cambridge, 1911), 103-26.

${ }^{2}$ This part of Stamford was in Northamptonshire at this point.

(c) The Author(s), 2021. Published by Cambridge University Press. This is an Open Access article, distributed under the terms of the Creative Commons Attribution licence (http://creativecommons.org/licenses/by/4.0/), which permits unrestricted re-use, distribution, and reproduction in any medium, provided the original work is properly cited.
} 
church of St Paul in the north-east of Stamford, where the members of the town's guild of St Katherine also met. Beaufort's gifts to Leche and White were far from deathbed acts of charity; rather, they honoured friendships which had developed between these women following Beaufort's move to Collyweston in Northamptonshire in 1487. The provisions made by Beaufort for Leche and White not only speak of the countess's renowned piety, they are also revealing of her belonging to a larger devotional community in the region, on which this article will focus.

\section{Urban piety}

The relationship between gender and piety in urban settings has been the subject of much scholarship in recent years. Together, these studies have painted a rich picture of urban devotion by addressing aspects such as charitable giving, the networks of devout women (and men) and piety both within and beyond the home. ${ }^{3}$ A core strand in such scholarship has been the identification of informal clusters or communities, which were defined by the shared geography and spiritual practices of their members. The recognition of a beguinage-like community of women in Norwich, for example, has raised questions around the distinctive nature of female piety in East Anglia, and the impact of continental mysticism on women's devotional practices in that region. ${ }^{4}$ In their work on late medieval York, both Jeremy Goldberg and Sarah Rees Jones have also notably identified examples of devout households and holy neighbourhoods, whose shared devotion to York's local archbishop martyr Richard Scrope defined their piety. ${ }^{5}$

\footnotetext{
${ }^{3}$ Most of these studies have focused on particular localities. For York, see P.H. Cullum and P.J.P. Goldberg, 'Charitable provision in late medieval York: "To the praise of God and the use of the poor", Northern History, 29 (1993), 24-39; P. Cullum, 'Vowesses and veiled widows: medieval female piety in the province of York', Northern History, 32 (1996), 21-41; J. Goldberg, 'Sir Richard Scrope, the devout widow, and the feast of Corpus Christi: exploring emotions, gender, and governance in early fifteenthcentury York', in S. Broomhall (ed.), Authority, Gender and Emotions in Late Medieval and Early Modern England (Basingstoke, 2015), 66-83; S. Rees Jones, 'Richard Scrope, the Bolton Hours and the church of St Martin in Micklegate: reconstructing a holy neighbourhood in later medieval York', in J. Goldberg (ed.), Richard Scrope: Archbishop, Rebel, Martyr (Donington, 2007), 214-36; S. Rees Jones and F. Riddy, 'The Bolton Hours of York: female domestic piety and the public sphere', in A.B. Mulder-Bakker and J. Wogan-Browne (eds.), Household, Women, and Christianities in Late Antiquity and the Middle Ages (Turnhout, 2005), 215-60. For Bristol, see C. Burgess, 'The Right Ordering of Souls': The Parish of All Saints Bristol on the Eve of the Reformation (Woodbridge, 2018); S.J. Adams, 'Religion, society and godly women: the nature of female piety in a late medieval urban community', University of Bristol Ph.D. thesis, 2001. For London and Westminster, see K. French, 'Loving friends: surviving widowhood in late medieval Westminster', Gender \& History, 22 (2010), 21-37; eadem, The Good Women of the Parish: Gender and Religion after the Black Death (Philadelphia, 2008). For Norwich, see N. Tanner, The Church in Late Medieval Norwich, 1370-1532 (Toronto, 1984); R. Gilchrist, Norwich Cathedral Close: The Evolution of the English Cathedral Landscape (Woodbridge, 2005).

${ }^{4}$ Tanner, The Church in Late Medieval Norwich. See also C. Hill, Women and Religion in Late Medieval Norwich (Woodbridge, 2010), and R. Gilchrist and M. Oliva, Religious Women in Medieval East Anglia: Studies in East Anglian History 1 (Norwich, 1993), 19-20.

${ }^{5}$ Goldberg, 'Richard Scrope, the devout widow'; Rees Jones, 'Richard Scrope, the Bolton Hours and the church of St Martin'.
} 
For Goldberg, the prioritization of spiritual ties offers an alternative devotional discourse to questions of economics, trade and patriarchal authority, which otherwise dominate studies of urban life. ${ }^{6}$ Despite the existence of a lively historiography surrounding lay devotion in major English cities, however, the informal pious practices of those in towns still await serious scholarly attention. The relationship between royal or aristocratic magnates and urban spaces has also been analysed for the most part from a political angle, rather than from cultural or social perspectives. $^{7}$ Discussions of great residences and urban spaces, meanwhile, have followed separate scholarly trajectories, meaning that the two are rarely considered together.

This article responds to these gaps in current scholarship by identifying and examining Margaret Beaufort's place at the heart of a flourishing devotional community, which centred on her great residence at Collyweston in Northamptonshire and the guild of St Katherine in the neighbouring market town of Stamford. The discussion illuminates a lively and dense network of individuals, among them a great many educated and influential women, who belonged to this milieu and defined its practices. This article posits that the Collyweston-Stamford circle should be regarded as an example of a 'devout society', a term coined by Mary Erler to describe the reading networks of the wealthy Norwich widow Margery Purdans, whose circle included laywomen, hermits, male and female anchorites and occasional clerks. ${ }^{8}$ Like Purdans' Norwich society, the Collyweston-Stamford circle included a broad array of individuals, who were united by their geography and shared devotional interests. As the ensuing discussion will demonstrate, there is likewise clear evidence of a prominent female culture, in which women - from vowesses and townswomen to anchoresses and nuns - played a leading role in transmitting religious ideas and texts across social, generational and urban-rural divides. By investigating the relationship between the king's mother and the inhabitants of Stamford, this article not only sheds new light on the devotional culture of a market town, but also on the ways in which Margaret Beaufort utilized her urban connections, particularly her female friendships, to demonstrate both her regional and national influence through her piety.

\section{Late medieval Stamford}

In the later Middle Ages, Stamford was one of England's leading towns on account of being a military and ecclesiastical centre and a locus of trade and industry. ${ }^{9}$ The town's favourable location close to the significant ports of Boston and Bishop's Lynn, and to major overland routes including the Great North Road and an east-west route stretching from the Wash to the urban centres of Coventry and Leicester, made for a vibrant and bustling community. Stamford was also home to a royal castle and was a hub of devotional activity, in part due to its close proximity to the religious centre of Peterborough, but also in its own right. Fourteen

\footnotetext{
${ }^{6}$ Goldberg, 'Richard Scrope, the devout widow', 79.

${ }^{7}$ For political perspectives, see E. Hartrich, Politics and the Urban Sector in Fifteenth-Century England, 1413-1471 (Oxford, 2019); C. Liddy, War, Politics and Finance in Late Medieval English Towns: Bristol, York and the Crown, 1350-1400 (Woodbridge, 2005).

${ }^{8}$ M.C. Erler, Women, Reading, and Piety in Late Medieval England (Cambridge, 2002), 71.

${ }^{9}$ A. Rogers, 'Late medieval Stamford: a study of the town council 1465-1492', in A. Everitt (ed.), Perspectives in English Urban History (London and Basingstoke, 1973), 16-38, at 17.
} 
parish churches, at least three religious houses and five friaries stood in the town. Ten medieval guilds are recorded, including that of St Katherine, which unusually supported two of the city's eight known anchoresses, to whom Margaret Beaufort made her bequests in $1508 .{ }^{10}$

Despite not being the richest or the most politically significant, St Katherine's is the best documented of Stamford's guilds owing to the survival of its guild register or Act Book for the years 1480 to $1534 .^{11}$ The guild's members, who by the late fifteenth century included many leading lights of the local community, met annually on the eve of Katherine's feast day and on the day itself ( 25 November) in the chapel above the south porch of the parish church of St Paul. ${ }^{12}$ The chapel had its own chaplain and contained an image of the saint to whom it was dedicated. New members were admitted on a yearly basis after the meeting on St Katherine's day eve, paying an entry fine of $6 s 8 d$ across four years, as well as an annual waxshot of $4 d$ or $2 d$ depending on whether they were a couple or single person respectively. The main guild feast took place on the Sunday following St Katherine's day. From 1480 onwards, the feast was held in the new guildhall which had been commissioned by the guild's then alderman, William Browne. ${ }^{13}$

The Brownes were a leading family of Stamford merchants who played a central role in the guild and made significant contributions to Stamford's economy and architecture, even after the centre of the wool trade had shifted to East Anglia. ${ }^{14}$ The most prolific member of the family in this regard was the aforementioned William Browne, an extremely wealthy and politically influential merchant and mayor of the Calais Staple who exported cloth and wool through the ports at Boston, Bishop's Lynn, Ipswich and London. ${ }^{15}$ In 1475, William and his wife Margaret founded the still extant Browne's hospital in Stamford, a joint hospital and guildhall with an elaborate chapel for ten poor men and two women, which stood on a plot of land adjacent to the couple's richly furnished home in All Saints' parish. ${ }^{16}$ William also contributed to the rebuilding of the neighbouring parish church where the members of his family worshipped. In 1480, he became alderman of St Katherine's, using this as an opportunity not only to improve the guild's physical fabric through his commission of the new hall, but also to attract new members in the form of prominent local citizens and county gentry. It was during William's term as alderman that the guild became linked to what Stamford historian Alan Rogers has described as a 'major social and cultural

\footnotetext{
${ }^{10}$ There are no known craft guilds in the town.

${ }^{11}$ Cambridge, Gonville and Caius College MSS 266/670. For a full transcription, see A. Rogers, The Act Book of St. Katherine's Gild, Stamford, 1480-1534 (Stamford, 2011) (hereafter Act Book).

${ }^{12}$ The chapel is now that of Stamford School.

${ }^{13}$ Act Book, 5.

${ }^{14}$ Act Book; Rogers, 'Late medieval Stamford', 22.

${ }^{15}$ A. Rogers, Noble Merchant: William Browne (c. 1410-1489) and Stamford in the Fifteenth Century (Bury St Edmunds, 2012); A. Rogers, 'Browne, William (d. 1489), merchant and benefactor', Oxford Dictionary of National Biography (ODNB), 4 Oct. 2007, www.oxforddnb.com/view/10.1093/ref:odnb/ 9780198614128.001.0001/odnb-9780198614128-e-94940, accessed 21 Feb. 2020.

${ }^{16} \mathrm{~N}$. Hill and A. Rogers, Guild, Hospital and Alderman: New Light on the Founding of Browne's Hospital, Stamford (Bury St Edmunds, 2013); J.P. Hoskins, D. John and P.A. Newton, The Hospital of William Browne, Merchant, Stamford, Lincolnshire: A History and an Account of the Buildings and Stained Glass (Stamford, 1970).
} 
focus in the region'. ${ }^{17}$ The guild evidently had a lasting impact on William: one of the few bequests in his short will is concerned with the long-term maintenance of the associated anchoress at St Paul's and her successors. ${ }^{18}$ Under the aldermanry of William's successor and nephew Christopher, the guild's membership diversified even further to include men from the religious orders, among them friars from the Austin and Grey friars, and the prior of the nearby St Leonard's Priory. ${ }^{19}$

St Katherine's was a mixed-sex guild, yet it is particularly notable for its high number of female members, most likely on account of the saint to whom it was dedicated, and its role in maintaining the town's two anchoresses. ${ }^{20}$ Guilds provided opportunities for female socialization and it would seem that St Katherine's offered pious wives and widows a forum through which to communicate their shared religious interests. ${ }^{21}$ In her Life, Katherine is represented as an exemplary model of chastity and learned piety, and she provided a didactic model for many laywomen to follow in their textual and pious endeavours. ${ }^{22}$ Katherine's image featured prominently in the iconographic schemes of the buildings of Stamford, including the guild chapel and also Browne's hospital, where she is still represented in the surviving stained glass windows today. ${ }^{23}$

A number of women connected to the guild appear to have taken vows of chastity during their widowhoods, a decision which they may have modelled on Katherine's example. In her detailed last will and testament of 1489, William Browne's widow and executrix Margaret left the nunnery of St Michael a bequest of money and the gown and mantle in which she had taken her vow of chastity. She also remembered the guild through highly personal bequests of domestic textiles, including a diaper tablecloth and towel from a chest in her great parlour. ${ }^{24}$ Following her husband's death, Margaret used her own seal and acted as a moneylender in the town, operating from the couple's sumptuously furnished townhouse in All Saints' parish. The house included several chambers, along with a parlour with a cupboard, a chapel chamber, kitchen and hall. The story of the patient Griselda was displayed prominently above the dais in the hall, no doubt as a fitting reminder of the obedience Margaret had pledged to God after William's death. Margaret's personal rooms comprised a solar, parlour and chamber, while the

\footnotetext{
${ }^{17}$ Act Book, 8.

${ }^{18}$ William Browne's will is transcribed in A. Rogers, 'Some kinship wills of the late fifteenth century from Stamford, Rutland and the surrounding area', Rutland Record, 28 (2008), 279-98, at 284-5.

${ }^{19}$ Act Book, 8.

${ }^{20}$ Devotion to St Katherine was widespread, yet the saint appears to have had a particular following among female devotees. For a regional take, see R. Kenney, 'Spalding's alliterative Katherine hymn: a guild connection from the south-east Midlands', Viator, 35 (2004), 455-82. Alan Rogers has noted that a relatively high number of women who joined the guild were named Katherine. See Act Book, 10.

${ }^{21}$ For women's involvement in guilds see French, The Good Women of the Parish, ch. 4.

${ }^{22}$ K.J. Lewis, The Cult of St Katherine of Alexandria in Late Medieval England (Woodbridge, 2000), 207-10.

${ }^{23}$ For the glass of Browne's hospital, see R. Mills, 'Panel of the month: King Solomon with a quotation from Proverbs', Vidimus, 18 (2008), https://vidimus.org/issues/issue-18/panel-of-the-month/, accessed 12 May 2020. I am grateful to Alan Rogers for bringing this to my attention.

${ }^{24}$ Margaret Browne's will is transcribed in Rogers, 'Some kinship wills', 285-7. For the significance of women's bequests of domestic textiles, see N.A. Lowe, 'Women's devotional bequests of textiles in the late medieval English parish church, c. 1350-1550, Gender \& History, 22 (2010), 407-29.
} 
outbuildings included a separate ale and brew house. During her short widowhood, Margaret also very likely continued the works on Browne's hospital with her brother Thomas Stokke, who was a rector of Easton on the Hill, just a mile and a half from Margaret Beaufort's Collyweston residence. ${ }^{25}$ The inclusion of a primer and several other textual objects in Margaret Browne's will reinforces the impression of a literate and intelligent woman. Indeed, Rogers has even suggested that she and her sister Agnes were educated at the school attached to St Michael's nunnery, where they would have learned to read, and perhaps even write, in the company of other wealthy daughters of Stamford. ${ }^{26}$

Like her sister and sister-in-law, Agnes Browne was a member of St Katherine's guild and had become a vowess following the death of her husband and William's brother John in $1476 .{ }^{27}$ Sometime before 1480, Agnes had given a domestic gift of a towel with blue tassels to the guild, and in her last will and testament she remembered the associated nunnery of St Michael through a bequest of $13 s 4 d^{28}$ The frontispiece of a beautifully illustrated Flemish prayer book, which is now in the collections of the Free Library of Philadelphia, survives as a fitting tribute to Agnes and John's lifetime wealth and piety. ${ }^{29}$ In the image, the couple is shown at prayer before the mass of St Gregory, to whom the family had an especial dedication. ${ }^{30}$ Agnes' fashionable attire, which includes a horned hairstyle, flowing pink dress and red rosary beads hanging from her waist, makes for a stark contrast with her more sombre depiction on the couple's funerary brass in All Saints' church, in which she is represented in her vowess robes.

The last will and testament of another wealthy townswoman and vowess, Margaret Spencer, which was drawn up some years later in 1509, further attests to the active role played by female guild members in Stamford's vibrant devotional community. ${ }^{31}$ Margaret had joined St Katherine's guild with her husband William in 1489 but was evidently widowed in or before 1500, from which point onwards she appears alone in the waxshot lists as ' $D\left[\right.$ omi]na Margaret Spencer'. ${ }^{32}$ Like Margaret Browne, Spencer spent her widowhood in her marital home, which stood next to the sign of the still extant George inn in Stamford St Martin's. ${ }^{33}$ This was a prestigious area of the

\footnotetext{
${ }^{25}$ Margaret Browne's will lists 'alle my tymbre, borde, Iryn, stone, lede, Nayle, Lath and alle other stuf perteynyng to bilding or Reparacion being within my place or els where be preserved and kept to my said brother for the Reparacions of the tenementis that stonden in feoffees handes'. See Rogers, 'Some kinship wills', 287.

${ }^{26}$ Rogers, 'Some kinship wills', 289. E. Power, Medieval English Nunneries, c. 1275 to 1535 (Cambridge, 1922), 897-901. Power is doubtful as to whether the girls would have learned to write, although she states that the type of education would have varied from convent to convent.

${ }^{27}$ L. Wood, 'Vowesses in the province of Canterbury, c. 1450-1540', University of London Ph.D. thesis, 2017, 61-5.

${ }^{28}$ Agnes' gift is recorded among the guild's goods in 1480. See Act Book, 25. Agnes' will no longer survives, yet a partial transcription of a later date is reproduced in Rogers, 'Some kinship wills', 283.

${ }^{29}$ Philadelphia Free Library, Widener MS 3, Browne Hours, fol. 7v, http://openn.library.upenn.edu/Data/ 0023/widener_003/data/web/6639_0017_web.jpg, accessed 26 Feb. 2020.

${ }^{30}$ See Rogers, 'Some kinship wills', 294.

${ }^{31}$ The National Archives (TNA) PROB 11/16/391. In her will, Margaret bequeaths 'my ringe whereby I was professed and made wowes' to her mother church at Lincoln.

${ }^{32}$ Act Book, 72, 123. Subsequent mentions to Spencer appear on pages 128, 14, 146, 152, 157 and 163.

${ }^{33}$ TNA PROB 11/16/391.
} 
town where a number of prominent citizens lived. Upon her death, Spencer made payments to the two anchoresses and specified that the nuns of St Michael's were to perform a dirige and mass of requiem in her memory. Her husband, meanwhile, was to be remembered separately by Friar Lewis of the Blackfriars. Spencer's main posthumous commission, however, was for the completion of the rood loft in her parish church, St Martin's, where she had requested burial in the porch alongside her husband. ${ }^{34}$ Her will goes into considerable detail about the iconographic scheme of the rood loft, on which there was to be an image of St Dorothy on the south side, a tabernacle of St Margaret on the north and images of saints Barbara and Katherine facing the chancel. These virgin martyr saints, Katherine included, had no doubt provided spiritual models for Margaret during her marriage, motherhood and chaste widowhood, and were likely intended to provide comfort to future generations of women (and men) who worshipped in the church.

\section{Margaret Beaufort and Stamford}

Margaret Beaufort gained the lordship of the town and manor of Stamford following the death of Edward IV's mother Cecily of York in 1495, at which point it had reverted to the crown. The reasons for Stamford passing to Margaret rather than Henry VII's queen Elizabeth of York have attracted little comment, yet it is likely that the decision formed part of a broader drive to assert Henry's legitimacy and royal influence in the Midlands through recourse to his maternal ties to the area. ${ }^{35}$ As a child, Margaret had spent considerable time at her mother Margaret Beauchamp's residence at Maxey, where she encountered a number of prominent visitors, among them the above-mentioned Margaret Browne (née Stokes). ${ }^{36}$ Originally from Warmington in Northamptonshire, Margaret Browne was a member of what Rogers has described as 'a close-knit group of like-minded people, clergy and laity, that centred on the Fairfax family of Deeping Gate', and who enjoyed Margaret Beauchamp's patronage. ${ }^{37}$ The close connections between the families is illustrated by the baptism of Ellen and William Fairfax's eldest daughter Margaret in Stamford, at which Margaret Browne and Margaret Beaufort's half-sisters, Edith and Elizabeth St John, acted as godmothers. ${ }^{38}$ Further links between the Browne and Beaufort families can be seen in the records relating to the prestigious Corpus Christi guild in Boston (Lincs), of which William Browne served as alderman in $1481 .{ }^{39}$ Margaret Beaufort and various members of

\footnotetext{
${ }^{34} \mathrm{Ibid}$.

${ }^{35}$ For more on this, see V. Rock, 'Shadow royals? The political use of the extended family of Margaret Beaufort', in S. Tyas and R. Eales (eds.), Family and Dynasty in Late Medieval England: Proceedings of the 1997 Harlaxton Symposium (Donington, 2003), 193-210.

${ }^{36}$ M.K. Jones and M. Underwood, The King's Mother: Lady Margaret Beaufort, Countess of Richmond and Derby (Cambridge, 1992), 132.

${ }^{37}$ Rogers, 'Browne, William (d. 1489)', ODNB. For the Stokes of Warmington, see A. Rogers, 'Eton's first "poor scholars": William and Thomas Stokes of Warmington, Northamptonshire (c. 1425-1495)', Northamptonshire Past and Present, 64 (2011), 5-21.

${ }^{38}$ Jones and Underwood, The King's Mother, 33; the Fairfax Hours is preserved as Oxford, Bodleian Library MS Lat. Liturg. e. 10. For a discussion, see A. Rogers, 'A fifteenth-century bible from Northamptonshire?', Nottingham Medieval Studies, 51 (2007), 167-79.

${ }^{39}$ Personal correspondence with Alan Rogers suggests that William Browne may have joined the Corpus Christi guild at the encouragement of his wife Margaret and her sister Agnes. Despite trading out of Boston
} 
her household were also members of this guild, including her constable at Maxey David Philip, along with Richard Fox, the Lincolnshire-born keeper of the privy seal, and her half-brother John Lord Welles. ${ }^{40}$

Beaufort maintained her links to the region throughout her life. During her third marriage to Henry Stafford, she and her husband spent most of their time at Bourne Castle, a manor house which offered spectacular views across the Lincolnshire fens from its rooftop gardens. ${ }^{41}$ In the 1470 s, Margaret had even made plans to be buried in Lincolnshire, only setting her sights on the grander environs of Westminster Abbey after her son's accession to the throne. Upon Margaret Beauchamp's death in 1482, Beaufort inherited the manors around Deeping and Maxey as part of her maternal inheritance. Five years later, she set up her own principal residence at Collyweston in Northamptonshire, which stood approximately ten miles from Maxey and three from Stamford.

Margaret's move to Collyweston in 1487 signalled her newfound status as king's mother and also her legal and financial independence as a femme sole. As Michael Jones and Malcolm Underwood argue, the establishment of Margaret's own household at Collyweston allowed for a forceful expression of her own personality. ${ }^{42}$ In 1499, Margaret took a vow of perpetual chastity whilst still married to her fourth husband Thomas Stanley, which she later renewed upon his death in 1504. It is against this self-fashioning as pious mother and matriarch that she transformed Collyweston from a manor house into a palace, through which she expressed her wealth, piety and status. ${ }^{43}$

Despite establishing her own powerbase just ten miles away, Margaret continued to use her mother's manor house at Maxey as an administrative centre for her Lincolnshire properties, in which she audited her receivers' accounts. ${ }^{44}$ Maxey was also used as an additional guesthouse during the wedding celebrations for Margaret's granddaughter Margaret Tudor in 1503, a number of elites with longstanding local connections being lodged there rather than at Collyweston during the two-week celebrations. The use of Maxey was no matter of convenience or coincidence. During the celebrations, Margaret Beaufort carefully orchestrated the use of space to emphasize her granddaughter's illustrious lineage and status, allowing only those who were related to Margaret Tudor by blood into the great hall at Collyweston to bid her farewell. ${ }^{45}$ Maxey thus formed part of a broader drive to assert the legitimacy of the fledgling Tudor dynasty through recourse to Margaret's maternal connections to the region.

for 40 years, William did not join the guild until 1476, the year in which his brother died and when Margaret and Agnes also joined, thus suggesting that the impetus to join the guild may have come from the female members of the family. I am grateful to Alan for sharing his thoughts on this with me.

${ }^{40}$ M.K. Jones, 'Lady Margaret Beaufort, the royal council and an early fenland drainage scheme', Lincolnshire History and Archaeology, 21 (1986), 11-18, at 13; Jones and Underwood, The King's Mother, 129.

${ }^{41}$ Jones and Underwood, The King's Mother, 137.

${ }^{42}$ Ibid., 170.

${ }^{43}$ For Collyweston, see M.K. Jones, 'Collyweston - an early Tudor palace', in D. Williams (ed.), England in the Fifteenth Century (Woodbridge, 1987), 129-41.

${ }^{44}$ Jones, 'Lady Margaret Beaufort, the royal council and an early fenland drainage scheme', 11.

${ }^{45}$ Jones and Underwood, The King's Mother, 74. 
The composition of Margaret's household also referenced her childhood connections. Several prominent Lincolnshire men were in her service, including Henry Hornby, who was secretary, dean of the chapel and later chancellor of her household, and Agnes Browne's son Christopher, who was a member of both her household and council, and whose manor house at Tolethorpe stood approximately six miles north of Collyweston. ${ }^{46}$ Christopher was a long-standing Beaufort ally, having accompanied Henry Tudor in exile in France. He was also a notable figure in regional politics, being three times a sheriff of Rutland, a JP in three counties and holding the office of mayor of the Boston staple in 1500. In Stamford, he served as alderman and mayor for the borough on three separate occasions, as well as acting as alderman of St Katherine's guild following his uncle's death in $1489 .{ }^{47}$ Margaret also honoured her long-standing ties to the Fairfax family through her patronage of the musician Robert Fairfax, who composed a new mass for her $1507 .{ }^{48}$

Margaret drew heavily on the local workforce when constructing and furnishing of her Collyweston household, among them a number of workers with connections to St Katherine's guild. Glaziers and joiners came from Stamford, and the goldsmith of the town was kept particularly busy with Margaret's requests, being tasked in a single year with gilding and repairing several items for her household chapel and closet. These included silver ewers, a pyx for housing the sacrament, a silver spoon, basins, candlesticks and a cup of gold from which she drank daily. ${ }^{49} \mathrm{~A}$ total payment of $£ 2311 d$ made to the goldsmith in 1502 suggests he made a healthy profit from Margaret's presence nearby ${ }^{50}$ Another Stamford craftsman, a pewterer named John Fisher who had been a member of St Katherine's guild since 1480, made three basins for the countess. ${ }^{51}$ Clothing for the members of Margaret's household was also sourced from Stamford: on one occasion, Thomas Jackson, a shoemaker who had joined St Katherine's guild with his wife Margaret in 1498, made 61 pairs of shoes for the alms men and women who lived on site at Collyweston. ${ }^{52}$

Unlike in Grantham, where she seems to have primarily exerted her influence through her close friend Bishop Richard Fox, Margaret Beaufort appears to have taken a close personal interest in Stamford and its inhabitants, making regular visits and charitable donations to various individuals and institutions there. ${ }^{53}$ On one occasion, she gave money to a poor man on crutches, and she rewarded a certain Leonard of the Vestry at Collyweston for healing the sick children of an

\footnotetext{
${ }^{46}$ For Hornby, see F. Kisby, 'A mirror of monarchy: music and musicians in the household chapel of Lady Margaret Beaufort, mother of King Henry VII', Early Music History, 16 (1997), 203-34, at 215; Jones and Underwood, The King's Mother, 168.

${ }^{47}$ Rogers, 'Browne, William', ODNB.

${ }^{48}$ Kisby, 'Mirror of monarchy', 224.

${ }^{49}$ The goldsmith's identity is unclear from Margaret's accounts, but he may have been Robert Goldsmyth, who joined St Katherine's guild with his wife Margaret in 1482. See Act Book, 42; St John's College, Cambridge (SJC), D91.20, 12, 28, 47, 50, 57, 77, 79.

${ }^{50}$ SJC D91.20, 65.

${ }^{51}$ Ibid., 50; Act Book, 36.

${ }^{52}$ SJC D91.20, 152; Act Book, 112.

${ }^{53}$ For Richard Fox and Grantham, see D. Stoker, 'The oratory, the apple cross and the gifts of Bishop Fox', in D. Stuart and D. Stoker (eds.), The Making of Grantham: The Medieval Town (Sleaford, 2011), $151-81$.
} 
impoverished woman in the town. ${ }^{54}$ Margaret was also a regular visitor to the nuns at St Michael's and the anchoresses associated with St Katherine's guild, to which the discussion will now turn.

\section{St Katherine's guild and female networks}

Margaret Beaufort joined St Katherine's guild in Stamford in 1502 and remained a member until her death seven years later. ${ }^{55}$ Margaret's decision to join the guild has traditionally been attributed to the influence of Christopher Browne, yet her devotion to St Katherine, who was renowned for her chastity and intellect, and the longstanding presence of an educated and pious female elite at the heart of the guild's membership, may have also been contributing factors. ${ }^{56}$ Like Margaret Spencer and many other vowesses, Beaufort appears to have had an especial fondness for Katherine, several objects and furnishings within her household featuring the saint's image. ${ }^{57}$ The countess is said to have fasted on Katherine's feast day, and the saint assumes pride of place on Margaret's funerary effigy in Westminster Abbey, where she is represented alongside the countess's namesake saint. ${ }^{58}$

Following her own enrolment, Margaret seems to have encouraged household members and friends to join the guild. In 1504, Elizabeth of York's sister Cecily enrolled alongside a 'servant of the king's mother'. This was the same year that Margaret White, who is referred to as the 'anchoress at the Nuns', also joined. ${ }^{59}$ Margaret Beaufort and Cecily enjoyed a close friendship, regularly exchanging personal gifts of books, clothing and devotional images. ${ }^{60}$ It would seem that Cecily's decision to join the guild was the result of Margaret's influence, and perhaps represented an extension of their shared domestic devotions at Collyweston, where Cecily had a room reserved for her use. ${ }^{61}$

The relationship between Margaret's household and St Katherine's guild was by no means one way. In addition to the above-mentioned servants and craftsmen who found long-standing or temporary employment within Margaret's residence, friars from the various houses of Stamford preached regularly at Collyweston, their presence informing the household's spiritual character. ${ }^{62}$ The countess seems to have been particularly impressed with the Austin friars, on one occasion contributing $66 s 8 d$ towards repairs to their friary, which stood in Stamford's western suburb. ${ }^{63}$

\footnotetext{
${ }^{54}$ SJC D91.20, 182, 38.

${ }^{55}$ Act Book, 139.

${ }^{56}$ Jones and Underwood, The King's Mother, 90.

${ }^{57}$ SJC D91.10, 2, 3.

${ }^{58} \mathrm{P}$. Lindley, “The singuler mediacion and praiers of al the holie companie of Heven”: sculptural functions and forms in Henry VII's chapel', in T.W.T. Tatton-Brown and R. Mortimer (eds.), Westminster Abbey: The Lady Chapel of Henry VII (Woodbridge, 2003), 259-94.

${ }^{59}$ Act Book, 144.

${ }^{60}$ In 1503, Margaret gave 'a fine image' to Cecily: SJC D91.21, 148. In 1504, Cecily gave Margaret a gown: SJC D91.21, 113.

${ }^{61}$ Cecily's second husband had been Margaret's half-brother John Welles, 1st Viscount Welles. Following his death, she married Lincolnshire esquire Thomas Kyme of Friskney, whose inferior status did not meet Henry VII's approval. Margaret subsequently sheltered Cecily in her household.

${ }^{62}$ SJC D91.20, 147; D91.21, 12, 139.

${ }^{63}$ SJC D91.20, 161.
} 
In May 1505, Margaret received three further guild members at Collyweston, namely the townswomen Elizabeth Radcliffe, Agnes Cecil and Joan Trygge. ${ }^{64}$ These women were married to some of Stamford's leading men, all of whom acted as aldermen (Stamford's equivalent of mayor) of the town in 1503, 1504 and 1505 respectively. ${ }^{65}$ Elizabeth and Joan had become members of St Katherine's guild with their husbands in the same year as Margaret Beaufort, while Agnes and David Cecil had joined five years earlier. ${ }^{66}$

The reason for the women's presence at Collyweston in the summer of 1505 is not recorded in Margaret's household accounts, yet it likely related to the enclosure of the anchoress Margaret White at St Michael's nunnery later that same year, particularly as Beaufort had visited the nuns and the two Stamford anchoresses just days earlier. ${ }^{67}$ Beaufort took a close personal interest in White's enclosure, commissioning a new cell for the anchoress and her servant on the north side of St Michael's. ${ }^{68}$ White's cell appears to have been relatively sumptuous, comprising four little chambers which were furnished with painted wall hangings and a canopied bed with new linen. ${ }^{69}$ It is possible that these chambers were arranged over different levels, in a style similar to the surviving anchorite's cell attached to the church of St Mary and St Cuthbert at Chester-le-Street in County Durham. ${ }^{70}$ Margaret also contributed to the cost of White's gown ahead of her enclosure, and she tasked Thomas Maidwell, a Stamford shoemaker who had joined St Katherine's guild with his wife Agnes in 1501, with making slippers and high pinsons or pumps, which were then delivered to White by Beaufort's servant Mistress Marbury. ${ }^{71}$ Beaufort also arranged for White's sister, who was a nun on the Isle of Sheppey in Kent, to stay at Collyweston with her servant for two months preceding

\footnotetext{
${ }^{64}$ SJC D91.21, 20.

${ }^{65}$ Little is known of Elizabeth's history prior to her marriage to William Radcliffe, who was a 'gentleman merchant' and alderman of Stamford four times in total. In 1500, he was also appointed as coroner of Stamford. William's lasting legacy in the town is Stamford grammar school, which he founded in 1532, ostensibly as a result of Margaret Beaufort's earlier encouragement. He also appears to have been involved in the leather trade, selling three hides to Margaret Beaufort's household in 1505/06. Alan Rogers has postulated that Elizabeth may have been the reason for William's move to Stamford, as he originally hailed from Yorkshire. It is also possible that she was the 'Mistress Ratcliffe gentlewoman' who attended Lady Margaret Beaufort at the funeral of Henry VII. Agnes Cecil was very likely a daughter or close relative of the Stamford glover, John Dycons. Agnes' husband David was alderman of Stamford on three occasions, and also served as a member of parliament for the town. He was connected to Margaret's household as a servant and kinsman of David Phillip (d. 1506), who was a steward of Collyweston and also lived in St George's parish in Stamford. Nicholas Trygge's career is less well documented, but by the late fifteenth century, he was acting as a notary of Stamford. He and his wife Joan appear regularly in the guild statutes relating to St Katherine's guild, of which he was also a clerk. On one occasion, he received a reward from Margaret Beaufort for travelling from Greatford in Lincolnshire to Liddington, although the reason for his journey is unspecified (SJC D91.20, 118). See A. Rogers, 'The parliamentary representation of Stamford from Edward IV to Henry VII', Nottingham Medieval Studies, 58 (2014), 185-252.

${ }^{66}$ Act Book, 107.

${ }^{67}$ SJC D91.21, 19.

${ }^{68}$ SJC D91.13, 98.

${ }^{69}$ SJC D91.20, 179.

${ }^{70} \mathrm{I}$ am grateful to Victoria Yuskaitis for bringing the Chester-Le-Street cell to my attention.

${ }^{71}$ SJC D91.21, 12, 181; Act Book, 131.
} 
the event. ${ }^{72}$ An entry relating to the transportation of Margaret White's belongings from London suggests that unlike the other Stamford anchoress Agnes Leche, who was from a well-known local family with long-standing connections to Stamford and Grantham, White was a newcomer to the town, who appears to have been summoned at Margaret Beaufort's request. ${ }^{73}$ Indeed, Eddie Jones has described White as a 'Beaufort protégé', and it is possible that Margaret Beaufort encouraged the anchoress to move closer to Collyweston so that the pair might maintain regular contact, particularly given the timing of White's enrolment into the guild alongside Cecily of York. ${ }^{74}$

White's withdrawal into her new cell appears to have taken place in December 1505. ${ }^{75}$ The tripartite ceremony included a mass, burial and enclosure, for which White would have publicly processed to her new anchorhold at St Michael's to the sound of prayers and psalms from the burial ritual. Although White's enclosure symbolically marked her death, her presence nevertheless brought status to the town, as anchoresses routinely provided spiritual guidance and advice to both local inhabitants and pilgrims. ${ }^{76}$ The enclosure of an anchorite, as Anneke Mulder-Bakker argues, also had performative power for faithful onlookers, whereby an earthly and sinful woman was transformed into a prophetess. ${ }^{77}$ Whilst watching White's procession to the anchorhold, Margaret Beaufort was no doubt reminded of her own commitment to God through her renewal of her vow of chastity in the previous year.

Given their social standing within the town and their membership of St Katherine's guild, it is likely that Joan Trygge, Elizabeth Radcliffe, Agnes Cecil and their husbands were also present for the occasion. The close involvement of the Radcliffes and Cecils in particular is evidenced by Margaret Beaufort's decision to make William Radcliffe responsible for the upkeep of White's cell after its initial construction. In her last will and testament, the countess also entrusted Radcliffe and David Cecil with the continued support and maintenance of White and her servant on her behalf after her death. ${ }^{78}$

William Radcliffe was also responsible for overseeing another of Beaufort's architectural commissions relating to the town's anchoresses. This project involved the construction of a door in the town wall, which gave the countess direct access to the back of the anchorhold attached to the north side of St Paul's church, where the other anchoress supported by St Katherine's guild, Agnes Leche, resided. ${ }^{79}$ The doorway constructed in the rear wall of Leche's cell afforded Margaret privileged

\footnotetext{
${ }^{72}$ SJC D91.20, 181, 183, 184, 186, 195.

${ }^{73}$ Ibid., 183.

${ }^{74}$ E.A. Jones, 'A new look into the speculum inclusorum', in M. Glasscoe (ed.), The Medieval Mystical Tradition: Exeter Symposium VI (Cambridge, 1999), 123-46.

${ }^{75}$ SJC D91.20, 185.

${ }^{76}$ The role of anchoresses as spiritual authorities is illustrated in the Book of Margery Kempe, in which Margery visits Julian of Norwich to seek spiritual guidance and affirm the validity of her visions. See Margery Kempe, Book of Margery Kempe, ed. and trans. B.A. Windeatt (Harmondsworth, 1985), 77.

${ }^{77}$ A.B. Mulder-Bakker, Lives of Anchoresses: The Rise of the Urban Recluse in Medieval England (Philadelphia, 2005), 70.

${ }^{78 ،}$ 'Will of Margaret Beaufort'.

${ }^{79}$ SJC D91.13, 98. The cell occupied the space between the north wall of the church and the town wall, which also formed the back wall of the anchorhold.
} 
and highly unusual access to the space of an anchorhold, which was otherwise the exclusive preserve of servants and confessors. Gifts of apples and wine brought by Margaret to one of the two Stamford anchoresses also speak of her close bonds with them, as edible gifts were commonly used to forge and celebrate friendships between lay and religious women. ${ }^{80}$ The power of food to create spiritual ties is also evidenced in its rejection. In Ancrene Wisse, an anonymously authored early thirteenth-century rule for anchoresses, the book's readers are advised not to eat with visitors so as to avoid becoming too friendly with them, while in the Book of Margery Kempe, an anchoress refuses to eat with Margery on account of her infamy. ${ }^{81}$ Margaret Beaufort's act of entering anchoresses' cells with gifts of food can thus be read as a marker of the close relationship between these women, and of Margaret's spiritual privileges as both king's mother and a vowess of exemplary reputation. ${ }^{82}$

It is probable that Margaret also exchanged books with White and Leche on her visits. Margaret regularly gave texts, including her own translations, to the nuns at Syon Abbey, where she had a room reserved for her use. She also ordered copies of her translation of the fourth book of Thomas à Kempis' De Imitatione Christi, 'On the Blessed Sacrament', for the members of her household. ${ }^{83}$ Margaret's translation of the Imitatio into English in 1504 has been regarded as instrumental in bringing Carthusian ideals to an audience beyond the cloister, and in bridging the divide between lay and secular households. ${ }^{84}$ Her reading tastes and habits were shared, as Erler argues, by friends, relatives and employees in and around Collyweston, evidence of which is found in the books circulated among them. ${ }^{85}$ Indeed, Diarmaid MacCulloch argues that the significant devotional library of Margaret's clerk of works James Morice shows strong influence of his mistress's cultivated piety. ${ }^{86} \mathrm{~A}$ printed primer bearing the names of Alexander Frogenhall, who was a servant in Margaret's household, and Mary Rivers, a gentlewoman who had a chamber reserved for her use at Collyweston, can also be linked to Margaret's ownership through its inclusion of two prayer cards from the Carthusian monastery at Sheen, where the countess was a regular visitor, along with a calendar of key events relating to the Tudor dynasty. ${ }^{87}$

\footnotetext{
${ }^{80}$ It is unclear from the household accounts which of the two Stamford anchoresses the gifts of apples and wine were intended for: see SJC D91.21, 156. For gifts of food, see C. Walker Bynum, Holy Feast, Holy Fast: The Religious Significance of Food to Medieval Women (Berkeley and Los Angeles, 1987); Erler, Women, Reading, and Piety, 17.

${ }^{81}$ Ancrene Wisse: A Guide for Anchoresses Based on Cambridge Corpus Christi College MS 402, ed. and trans. B. Millett (Exeter, 2000), 56; Kempe, Book of Margery Kempe, 113.

${ }^{82}$ These same privileges also underpinned Margaret Beaufort's special dispensation to visit and reside at Syon Abbey, where she had a room reserved for her use.

${ }^{83}$ S. Powell, 'The Lady Margaret Beaufort and her books', The Library, Sixth Series, 20 (1998), 197-240; M.C. Erler, 'The laity', in V. Gillespie and S. Powell (eds.), A Companion to the Early Printed Book in Britain, 1476-1558 (Cambridge, 2014), 134-49.

${ }^{84}$ B.M. Hosington, 'Lady Margaret Beaufort's translations as mirrors of practical piety', in M. White (ed.), English Women, Religion, and Textual Production, 1500-1625 (Burlington, VT, 2011), 185-203, at 189-90.

${ }^{85}$ See Erler, 'Laity'.

${ }^{86}$ MacCulloch quoted in ibid., 145.

${ }^{87}$ Erler, 'Laity', 143.
} 
As with St Katherine's guild, the members of Margaret's household reading circle included both sexes, yet the prevalence of women is again notable. ${ }^{88}$ Felicity Riddy argues that all-female reading communities were a prominent and distinctive feature of late medieval aristocratic and gentry households at this time, with many elite women belonging to expansive female reading communities which transcended social, generational and familial boundaries. Through their belonging to these female reading groups, women were able to construct a self 'whose femininity [was] its strength' ${ }^{89}$ A surviving book of hours gifted from Margaret Beaufort to Lady Anne Shirley reveals how female reading communities created ties of loyalty and obligation between women. In exchange for the book, Margaret asked to be remembered in Lady Shirley's prayers, writing: 'my good lady Shyrley pray for me that gevythe yow thys booke y hertely pray yow, Margaret modyr to the Kynge'. ${ }^{90}$ Although they were unable to visit Collyweston in person, it is likely that the anchoresses of Stamford participated in this reading circle through their close and regular contact with the countess. It is also probable that educated Stamford townswomen with connections to Margaret's household and St Katherine's guild, Elizabeth Radcliffe, Agnes Cecil and Joan Trygge among them, played a role in circulating texts and ideas to other members of the devout society.

Margaret's apparent interest in Carthusian works from around 1504 raises the possibility that she came into contact with one particular manuscript associated with the Stamford circle. In that same year, William Browne's priest and chaplain John Trus gifted an English translation of the Speculum Inclusorum or 'The Myrour of Recluses' (British Library MS Harley 2372) to Browne's hospital. The anonymously authored text appears to have been adapted from the Latin for a female readership, specifically an anchoress. While Alan Rogers has suggested that the manuscript passed from Browne to Trus and then back to Browne's hospital when Trus departed in 1504, Eddie Jones has sought to link the work to a Stamford anchoress with Carthusian connections, namely Margaret White. ${ }^{91}$ The two views, however, are not necessarily incompatible, particularly when Trus, Browne and White are considered as part of a devotional circle of readers.

Although there are no direct identifying features to link the book with Margaret Beaufort, her sponsorship of White and her apparent interest in Carthusian works at this time make it probable that she knew of the manuscript, particularly given the communal nature of reading and her active presence in Stamford at this point. Just months earlier, in December 1503, Beaufort had visited Browne's hospital to hear a sermon delivered by the master. ${ }^{92}$ It is also likely that she knew Trus through her connections to the University of Oxford, as Rogers makes a convincing case for Trus being the same person as John Taylor, a fellow of Oriel College between 1489 and 1502, who later became treasurer of Oriel and principal of St Mary

\footnotetext{
${ }^{88}$ Erler, Women, Reading, and Piety, 124; eadem, 'Laity', 134-49.

${ }^{89}$ F. Riddy, 'Women talking about the things of God: a late medieval sub-culture', in C.M. Meale (ed.), Women and Literature in Britain, 1150-1500 (Cambridge, 1993), 104-27, at 111-12.

${ }^{90}$ SJC MS N.24, fol. 13r.

${ }^{91}$ Jones, 'New look into the speculum'; A. Rogers, 'The ownership of The Myrour of Recluses (British Library, MS Harley 2372) in the late fifteenth century', The Library, 15 (2014), 187-94.

${ }^{92}$ SJC D91.20, 124.
} 
Hall. ${ }^{93}$ Margaret had close links with the College: her first theology lecturer at Oxford was Edmund Wilsford of Oriel, and a certain Master Powell from the same college came to preach before her at Collyweston in $1503 .{ }^{94}$ If Trus was indeed Taylor, it seems very likely that he and Margaret had crossed paths. ${ }^{95}$

A further aspect of the manuscript that would have appealed to Margaret is its inclusion of medical advice, including a cure for gout. While gout was a condition that could have feasibly affected any number of the book's readers, Henry VII is known to have had recurrent bouts around this time. So severe were Henry's symptoms in 1507 that Margaret moved in with her son at Richmond Palace. ${ }^{96}$ Numerous manuscripts associated with Margaret Beaufort also contain medicinal remedies, including British Library Royal 2 A XVIII, which contains notes on the merits of rosemary and a cure for headaches added around the year 1500. Margaret also owned a compilation of prayers and tracts against the plague (Fitzwilliam Museum MS 261) and her closet at Collyweston contained an alembic and stills for the distillation of medicines. ${ }^{97}$ The countess also regularly rewarded others, including the vicar of St Stephen's in Stamford, for distilling waters, and she received rose water on numerous occasions from female friends and associates. ${ }^{98}$ Margaret's evident interest in medicine and her son's condition around this time suggests that the manuscript's contents would have appealed to her for more reasons than one, and thus it may well have passed through her hands as a sponsor of the Stamford circle.

\section{Closet and anchorhold}

At the same time as she was making payments for the works on Leche's and White's cells, Margaret Beaufort was putting the finishing touches to her new personal suite of rooms at Collyweston..$^{99}$ Margaret's new apartments comprised a series of interconnected chambers, culminating in a bedchamber and a prayer closet, which was connected to her magnificent household chapel via a gallery. From her prayer closet, Margaret had privileged and uninterrupted views onto the altar and the raising of the Host, not dissimilar to those enjoyed by White and Leche through the squints in their cells. The construction of White's cell by the same workmen who were tasked with building Margaret's new rooms at Collyweston likewise suggests that the two structures shared similarities in their design. White's cell may have also borne external evidence of Beaufort's patronage in the form of carved badges and heraldic insignia, much like the almshouse in the kitchen yard at Collyweston, on which heraldic badges were displayed. ${ }^{100}$

\footnotetext{
${ }^{93}$ Rogers, 'Ownership of The Myrour'.

${ }^{94}$ SJC D91.20, 101.

${ }^{95}$ John Taylor was also an executor of Margaret Spencer's will, by which point he was vicar of St Martin's church in Stamford. TNA PROB 11/16/391. See also Rogers, 'Ownership of The Myrour', 190.

${ }^{96}$ E. Lane Furdell, The Royal Doctors, 1485-1714: Medical Personnel at the Tudor and Stuart Courts (New York, 2001), 19.

${ }^{97}$ SJC D91.5, 22.

${ }^{98}$ SJC D91.21, 163. See also R.M. Delman, “....for bryngyng of rose water to my lady grace”: enclosed gardens, female networks, and spiritual kinship in late medieval northern Europe', Viator, forthcoming 2021.

${ }^{99}$ SJC D91.13, 10, 31; D91.22, 22.

${ }^{100}$ For the almshouse at Collyweston, see SJC D91.14, 69; D91.22, 13.
} 
Beaufort's and White's rooms were not only connected through their materiality, but also through their use. In the year that her new rooms at Collyweston were completed, Beaufort also finished her above-mentioned translation of the fourth book of Thomas à Kempis' Imitatio. The book's advice on meditative devotion and the correct way to receive the sacrament would have been highly pertinent to the space of the closet, being described in the library catalogue of Syon Abbey as 'solitariis et contemplativis utilis', that is to say useful for those of a solitary and contemplative nature. ${ }^{101}$

The close connection between physical and textual space was recognized by other noblewomen at this time. Two of Margaret's near-contemporaries, Isabella of Portugal, duchess of Burgundy (d. 1471), and her daughter-in-law, Margaret of York (d. 1503), commissioned new closets concurrent with their requests for spiritual treatises from their confessors. ${ }^{102}$ Ezekiel Lotz observes that the texts commissioned by the two duchesses of Burgundy encouraged the women to reimagine their closets and bedchambers as cells akin to the anchorhold. Through their meditative devotions, Isabella and Margaret were thus able to cultivate and inhabit sacred spaces without renouncing their ties to the secular world, a notion that would have been particularly appealing to a vowess such as Margaret Beaufort. ${ }^{103}$ The close links between secluded domestic space and textuality are also emphasized in John Capgrave's mid-fifteenth-century Life of St Katherine, in which the saint devises a walled palace and great garden in which to study. This was:

...fer away fro every manere wyght

It was made and ordeynd at hir owyn devyse

There wold sche ly sumtyme, stody and wright

...Solitary lyf to stodyers is comfort. ${ }^{104}$

In light of these observations, the timing of Margaret's building activities at Collyweston and Stamford become all the more striking. Margaret's simultaneous undertakings of translating the Imitatio, of completing her new bedchamber and prayer closet at Collyweston and of commissioning works to Leche's and White's cells can thus be read as interlinked acts of pious self-fashioning. Viewed together, they are indicative of the ways in which Margaret Beaufort conceived of and performed her authority during her widowhood, her architectural and meditative withdrawal likening her to her Stamford sisters in the anchorhold, and to St Katherine, to whom the members of Stamford's devout circle were dedicated.

\footnotetext{
${ }^{101}$ Hosington, 'Lady Margaret Beaufort's translations', 193.

${ }^{102}$ E. Lotz, 'Secret rooms: private spaces for private prayer in late-medieval Burgundy and the Netherlands', in J. Luxford (ed.), Studies in Carthusian Monasticism in the Late Middle Ages (Turnhout, 2008), 163-77.

${ }^{103}$ Ibid.

${ }^{104}$ J. Capgrave, The Life of Saint Katherine: Book 1, ed. K.A. Winstead, https://d.lib.rochester.edu/teams/ text/winstead-capgrave-life-of-saint-katherine-book-1, accessed 29 Sep. 2020: 'Far away from everyone/it was made according to her own design/There would she lay sometimes, study and write/...solitary living to scholars is a comfort' (translation my own).
} 


\section{Conclusion}

Through its investigation of a devout society centred on the market town of Stamford and Margaret Beaufort's nearby residence at Collyweston, this article has made a new contribution to scholarship concerned with affective piety and ties of spiritual kinship within an urban context. The adoption of a devotional lens has unveiled Margaret Beaufort's considerable influence in Stamford, particularly following the death of her fourth husband Thomas Stanley and renewal of her vow of chastity in 1504. From her nearby powerbase at Collyweston, Margaret used her philanthropy, her support for the two Stamford anchoresses and her textual practices as a means of cultivating and extending networks that had been fostered by her mother Margaret Beauchamp some years earlier. This, however, was not a top down process; rather, Beaufort both contributed to and benefited from an already flourishing devout society, of which the guild of St Katherine and its associated anchoresses were a focal point. Beaufort's frequent visits to Stamford and the presence of the town's inhabitants within her household as guests, visitors and employees, are revealing of the mutually supportive relationship between elite residence and guild, which offered twin stages on which these spiritual ties were created and celebrated.

While the Collyweston-Stamford circle included a range of individuals, this article has identified clear evidence of prominent female culture, in which both lay and religious women played a significant role in the circulation of ideas, texts and pious practices across generational, social and urban-rural divides. The longstanding presence of vowesses among the guild's members may have even in part determined Beaufort's own decision to join in 1502 and renew her vow of chastity two years later, the point at which the anchoress Margaret White became a member, and when Beaufort was completing her own rooms at Collyweston. For Margaret Beaufort and the devout women of Stamford, the virgin martyr St Katherine provided an exemplary and authorizing model, validating their literary and pious activities which centred on the guild founded in her honour. Thus, while the inhabitants of Stamford gained the support of a wealthy, influential and pious patron who enriched the physical and social fabric of their town, Margaret Beaufort was able to nurture and extend the matrilineal ties on which her matriarchal authority rested, so as to articulate her domestic and wider authority in spiritual terms.

Cite this article: Delman RM (2022). The vowesses, the anchoresses and the aldermen's wives: Lady Margaret Beaufort and the devout society of late medieval Stamford. Urban History 49, 248-264. https://doi.org/10.1017/S096392682100002X 